Supplement of Biogeosciences, 16, 4875-4888, 2019

https://doi.org/10.5194/bg-16-4875-2019-supplement

(C) Author(s) 2019. This work is distributed under

the Creative Commons Attribution 4.0 License.

(c) (1)

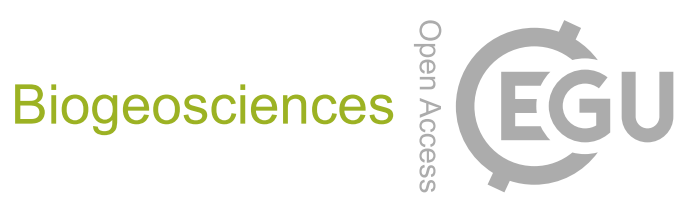

Supplement of

\title{
Metabolic tradeoffs and heterogeneity in microbial responses to tempera- ture determine the fate of litter carbon in simulations of a warmer world
}

Grace Pold et al.

Correspondence to: Grace Pold (apold@umass.edu)

The copyright of individual parts of the supplement might differ from the CC BY 4.0 License. 


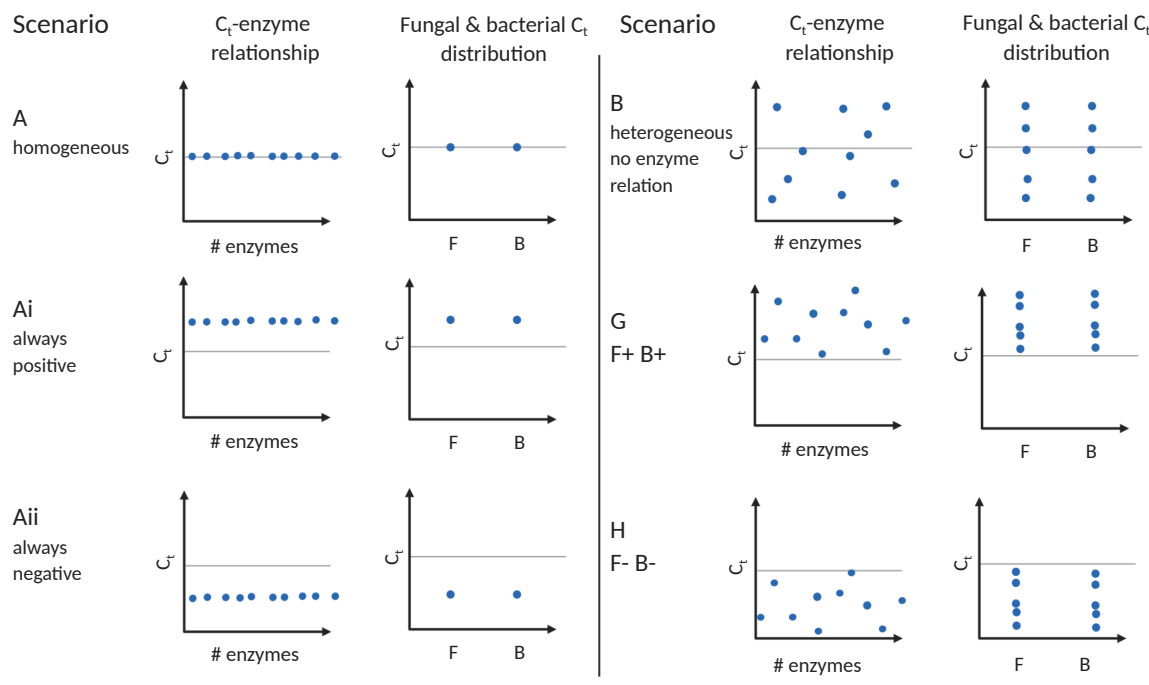

Figure S1. Schematic of experimental design used for assessing the effect of heterogeneity in $C_{t}$ on DEMENT outputs. Letters denoting parts of figure 1 in the main text are retained to facilitate cross-comparison of scenarios, so are not contiguous within the plot. $\mathrm{C}_{\mathrm{t}}$ is the same across all taxa, and is set to $0^{\circ} \mathrm{C}^{-1}(\mathrm{~A}), 0.011{ }^{\circ} \mathrm{C}^{-1}\left(\mathrm{~A}_{\mathrm{i}}\right)$, or $-0.011{ }^{\circ} \mathrm{C}^{-1}\left(\mathrm{~A}_{\mathrm{ii}}\right)$. These "homogeneous" values correspond to the mean starting cross-taxon average $\mathrm{C}_{\mathrm{t}}$ of the adjacent heterogeneous scenario in the figure: -0.022 to $0.022^{\circ} \mathrm{C}^{-1}$ (scenarios $\mathrm{A}$ and $\mathrm{B}$ ); o to $0.022{ }^{\circ} \mathrm{C}^{-1}$ (scenarios $\mathrm{A}_{\mathrm{i}}$ and $\mathrm{G}$ ); -0.022 to $0{ }^{\circ} \mathrm{C}^{-1}$ (scenarios $\mathrm{A}_{\mathrm{ii}}$ and $\mathrm{H}$ ). Each point represents the combination of traits one mock taxon in the model might have, although 100 taxa were actually used in the simulations. Horizontal dashed lines indicate a $C_{t}$ of zero, and clusters of points above and below this line denote when CUE tends to increase or decrease with increasing temperature. The letters $\mathrm{F}$ and $\mathrm{B}$ in the $\mathrm{x}$-axis of individual graphs denote sensitivities for fungi and bacteria, respectively. The trait values for different mock taxa may not be visible if the values for the traits on the two axes are identical. Figure prepared in BioRender

Table S1. Effect of changing the reference CUE and enzyme costs against CUE on the stability and concievability of DEMENT outputs under three warming scenarios. CUE_ref is the $\mathrm{CUE}$ at $15^{\circ} \mathrm{C}$, prior to calculating enzyme costs. $\mathrm{C}_{\mathrm{t}}$ describes whether CUE is homogeneous or heterogeneous between taxa. CUE_enz is the maximum cost against CUE for enzyme production (with transporter costs parameterized the same). Stable is the fraction of runs where the microbial community constrained litter accumulation until the end. The median MBC, SOC:MBC ratio, and SOC are shown, along with the biomass-weighted CUE of the active community at the end of this time. CN, CP, and NP refer to median elemental ratios of microbial biomass. Italicized values are those not deemed to be within the range of biologically plausible values.

\begin{tabular}{|c|c|c|c|c|c|c|c|c|c|c|c|}
\hline CUE_ref & $\mathrm{C}_{\mathrm{t}}$ & Temperature & CUE_enz & Stable & MedianMBC & Median SOC:MBC & Median SOC & Final CUE & $\mathrm{CN}$ & $\mathrm{CP}$ & NP \\
\hline \multirow{3}{*}{0.58} & homogeneous & $\mathrm{H}$ & -0.1 & 0.71 & 57 & 3.4 & 198 & 0.44 & 4.5 & 49 & 9.3 \\
\hline & NA & $\mathrm{C}$ & -0.1 & 0.97 & 67 & 2.3 & 142 & 0.41 & 4.6 & 43 & 9.3 \\
\hline & heterogeneous & $\mathrm{H}$ & -0.1 & 0.86 & 107 & 1.4 & 144 & 0.53 & 4.7 & 43 & 9 \\
\hline \multirow[t]{2}{*}{0.48} & NA & $\mathrm{C}$ & -0.1 & 0.93 & 37 & 7.6 & 241 & 0.31 & 4.3 & 39 & 9.1 \\
\hline & heterogeneous & $\mathrm{H}$ & -0.1 & 0.9 & 70 & 2.1 & 137 & 0.42 & 4.6 & 42 & 9.3 \\
\hline 0.48 & homogeneous & $\mathrm{H}$ & -0.2 & 0.64 & 20 & 54 & 1041 & 0.23 & 4.5 & 41 & 9.2 \\
\hline \multirow{3}{*}{0.38} & homogeneous & $\mathrm{H}$ & -0.1 & 0.95 & 20 & 32 & 637 & 0.23 & 4.4 & 39 & 9 \\
\hline & NA & $\mathrm{C}$ & -0.1 & 0.95 & 20 & 33 & 492 & 0.22 & 3.8 & 37 & 9.3 \\
\hline & heterogeneous & $\mathrm{H}$ & -0.1 & 0.98 & 38 & 7.2 & 219 & 0.32 & 4.1 & 38 & 9.2 \\
\hline
\end{tabular}



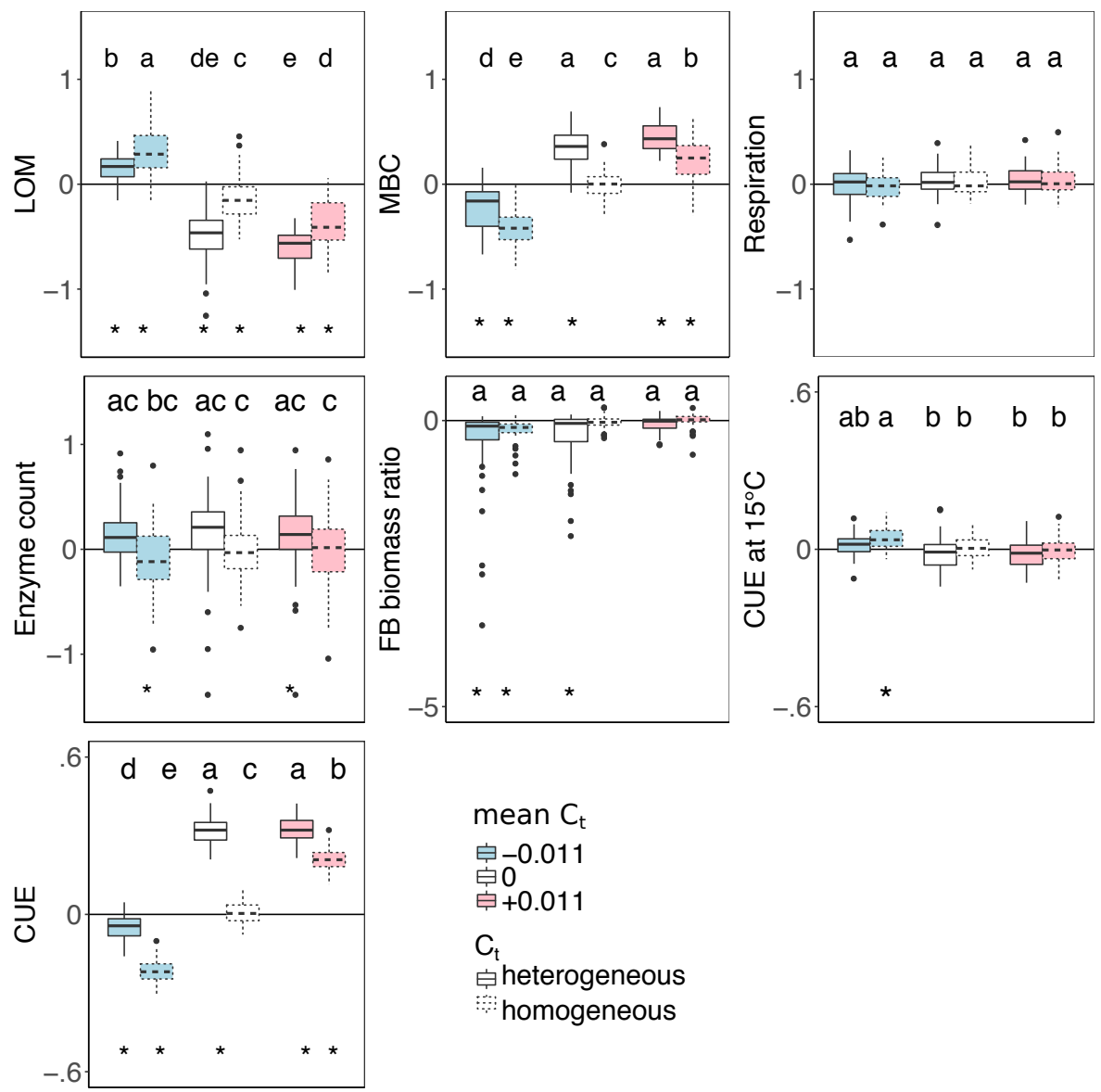

mean $\mathrm{C}_{\mathrm{t}}$

白-0.011

官 0

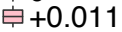

$\mathrm{C}_{\mathrm{t}}$

官heterogeneous

homogeneous

Figure S2. Effect of $5^{\circ} \mathrm{C}$ warming on $\mathrm{C}$ stocks and flows in simulations, reported as the natural log of the ratio of the values in heated compared to control conditions. Here, the CUE temperature response is allowed to vary (heterogeneous) or is fixed (homogeneous) at the mean cross-taxon value as in Figure 3 , but the variability is either constrained to all negative values (mean of $-0.011^{\circ} \mathrm{C}^{-1}$; range -0.022 to $0^{\circ} \mathrm{C}^{-1}$ ), or all positive values (mean of $0.011^{\circ} \mathrm{C}^{-1}$; range 0 to $0.022^{\circ} \mathrm{C}^{-1}$ ) 
Table S2. Median (or median-standardized interquartile range (IQRm)) output values for DEMENT model runs where $C_{t}$ was either always positive, or always negative, marked according to warming effect (+/-) and model structure effects (letters) determined using Bonferonicorrected post-hoc tests following linear mixed effect models. Symbols: "+" warming increased value; "-" warming decreased value). Letters: differences between warmed scenarios. In some instances, values differ slightly from those in Table 1 because some seeds failed to lead to constrained LOM accumulation and so were removed here.

\begin{tabular}{|c|c|c|c|c|}
\hline $\begin{array}{l}\text { Figure } 1 \text { scenario } \\
\qquad \mathrm{C}_{\mathrm{t}}\left({ }^{\circ} \mathrm{C}^{-1}\right)\end{array}$ & $\begin{array}{c}\mathrm{A}_{\mathrm{i}} \\
-0.011\end{array}$ & $\begin{array}{c}\mathrm{G} \\
-0.022 \text { to } 0\end{array}$ & $\begin{array}{c}\mathrm{A}_{\mathrm{ii}} \\
+0.011\end{array}$ & $\begin{array}{c}\mathrm{H} \\
0 \text { to } 0.011\end{array}$ \\
\hline LOM IQRm & 0.29 & 0.23 & 0.21 & 0.30 \\
\hline SOM IQRm & 0.26 & 0.15 & 0.21 & 0.19 \\
\hline Enzyme count & $16.5 b$ & $19 \mathrm{a}$ & $15 b-$ & $18 \mathrm{a}$ \\
\hline Shannon's H & $1.92 \mathrm{a}$ & $1.61 \mathrm{a}$ & $1.86 \mathrm{ac}$ & $1.64 \mathrm{bc}-$ \\
\hline $\operatorname{MBC}\left(\mathrm{mg} \mathrm{cm}^{-3}\right)$ & $26.5 b+$ & $32.3 \mathrm{a}+$ & $13.6 \mathrm{~d}-$ & $17.2 \mathrm{c}-$ \\
\hline $\operatorname{LOM}\left(\mathrm{mg} \mathrm{cm}^{-3}\right)$ & $411.5 c-$ & $334.6 d-$ & $841.8 \mathrm{a}+$ & $706.5 b+$ \\
\hline $\mathrm{CUE}$ at $15^{\circ} \mathrm{C}$ & $0.23 \mathrm{bc}$ & $0.23 \mathrm{c}$ & $0.24 a+$ & $0.23 b$ \\
\hline CUE at $20^{\circ} \mathrm{C}$ & $0.29 b+$ & $0.32 \mathrm{a}+$ & $0.19 \mathrm{~d}-$ & $0.22 \mathrm{c}-$ \\
\hline FB biomass ratio & $0.85 \mathrm{a}$ & $0.81 \mathrm{ac}$ & $0.73 b c$ & $0.68 b$ \\
\hline Respiration $\left(\mathrm{mg} \mathrm{cm}^{-3} \mathrm{day}^{-1}\right)$ & $0.94 \mathrm{c}$ & $0.96 \mathrm{ac}$ & $0.90 \mathrm{~b}$ & $0.94 \mathrm{abc}$ \\
\hline FB richness ratio & $0.51 \mathrm{a}$ & $0.46 \mathrm{ac}$ & $0.40 \mathrm{bc}$ & $0.43 \mathrm{ac}$ \\
\hline CUE bacteria & $0.27 b$ & $0.36 \mathrm{a}+$ & $0.27 b$ & $0.25 c-$ \\
\hline CUE fungus & $0.22 \mathrm{c}$ & $0.29 a+$ & $0.23 b+$ & $0.18 \mathrm{~d}-$ \\
\hline
\end{tabular}

